\title{
Estimating the joint roughness coefficient of discontinuities found in metamorphic rocks
}

\author{
Pedro Santarém Andrade · António Almeida Saraiva
}

Received: 18 December 2007 / Accepted: 10 April 2008/Published online: 16 May 2008

(C) Springer-Verlag 2008

\begin{abstract}
The paper presents the results of different methods of determining the roughness of joints in quartzites, metagreywackes and phyllites obtained from road cuts in central Portugal. The evaluation of the joint roughness coefficient (JRC) was carried out using graphical and analytical procedures. Differences were found between the JRC graphic and the JRC calculated, depending on the method used. The JRC calculated values obtained by the tilt tests and the Schmidt rebound hammer tests were compared to the JRC calculated values established from the rock joint shear tests. It is concluded that if JRC is to be used, it is essential to specify how it was established.
\end{abstract}

Keywords Joint Roughness Coefficient .

Discontinuities characteristics - Tilt tests .

Rock joint shear tests - Amplitude roughness ·

Metamorphic rocks

Résumé Cet article présente les résultats de différentes méthodes de déterminer la rugosité des discontinuités trouvées dans des quartzites, métagrauwackes et schistes obtenus dans des talus des routes au centre de Portugal. L'évaluation du Coefficient de Rugosité du Joint Joint Roughness Coefficient (JRC) a été réalisée à travers des procédures analytiques et graphiques. Des différences entre le JRC graphique et le JRC calculé sont trouvées selon les méthodes employées. Les valeurs du JRC obtenues par les essais d'inclinaison (tilt tests) et les essais de dureté par

P. S. Andrade $(\bowtie) \cdot$ A. A. Saraiva

Department of Earth Sciences, University of Coimbra,

Coimbra, Portugal

e-mail: pandrade@dct.uc.pt

A. A. Saraiva

e-mail: asaraiva@dct.uc.pt marteau de Schmidt ont été comparées aux valeurs du JRC calculées à partir des essais de cisaillement des discontinuités. On conclu qu'il est fondamental d'indiquer comment le JRC a été établit.

Mots clés Joint Roughness Coefficient .

Caractéristiques des discontinuités · Essais d'inclinaison · Essais de cisaillement des discontinuités .

Amplitude de la rugosité · Roches métamorphiques

\section{Introduction}

Discontinuities are surfaces with a geological origin which are present in all rock masses. The mechanical strength of the rock masses is conditioned by the discontinuity characteristics, which affect rock slope stability and excavations into rock masses.

Hoek (2007) draws attention to the importance of the discontinuity roughness when determining the shear strength of a rock mass and the stability of excavations in rock masses. Other discontinuity characteristics which influence the shear strength are: the aperture; the type, thickness and water content of the infill material; the extent of weathering of the discontinuity walls; the presence and movement of water; the rock type; and the orientation of the discontinuities in relation to the state of the "in situ" stresses.

Roughness can be defined according to a profile or a surface. The roughness profile is determined by the irregularity of the discontinuity surface in relation to a reference plane (Hack Price and Rengers 2003). In this work, open discontinuities (without visible infill material) were studied and their roughness was defined using the joint roughness coefficient (JRC). 
Various authors have tried to define the shear strength of discontinuities without infill material. One of the empirical models was established by Barton and Choubey (1977) and Barton and Bandis (1990):

$\tau=\sigma_{n}^{\prime} \operatorname{tg}\left[\mathrm{JRC} \log _{10}\left(\mathrm{JCS} / \sigma_{n}^{\prime}\right)+\phi_{r}\right]$

where: $\tau=$ shear strength, $\sigma_{n}^{\prime}=$ normal effective stress acting on a plane on which the shear strength is mobilized, JCS $=$ joint wall compressive strength and $\phi_{r}=$ residual angle of friction.

The JRC can be defined using graphic methods which are effective and avoid the difficulties of obtaining suitable samples or rock. In this work, the JRC graphic was obtained using the needle comb method and the profiles obtained were visually compared with ten typical roughness profiles from Barton and Choubey (1977). As this method involves some subjectivity, the results obtained may vary depending on the different evaluators. The needle comb used had a length of $300 \mathrm{~mm}$ with the capability of measuring vertical amplitudes of up to $70 \mathrm{~mm}$.

Rock specimens 100 to $140 \mathrm{~mm}$ long and $100 \mathrm{~mm}$ wide were used so that the results could be compared with the profiles presented by Barton and Choubey (1977). The lowest JRC values (0-5) relate to discontinuity surfaces generally associated with planar foliation such as schistosity, while the rougher discontinuities, with values of between 15 and 20, are generally related to tension fractures.

As well as the definition of the JRC by graphical means, their determination can also be obtained using statistical or geostatistical methods or by involving fractal theory. Some geomechanical classifications such as the Q-system use the JRC values as a parameter. These classifications present a considerable degree of uncertainly and some qualitative characteristics. However, the values of the JRC can also be obtained using tilt tests and the Schmidt rebound hammer tests following Eq. 2:

$\mathrm{JRC}=\left(\alpha-\phi_{r}\right) / \log _{10}\left(\mathrm{JCS} / \sigma_{\mathrm{ns}}^{\prime}\right)$

where $\alpha=$ tilt test angle - at which the upper part of the sample slides on the lower part, $\sigma_{\mathrm{ns}}^{\prime}=$ the normal effective stress when the sliding occurs.

Discontinuities in three different lithologies were studied:

(a) Quartzites - in which the discontinuity surfaces are related with stratification.

(b) Phyllites-where the discontinuities are related to schistosity.

(c) Metagreywackes - in which the discontinuities coincide with the schistosity cleavage surfaces and/or spaced cleavage.
The quartzites were obtained from a $150 \mathrm{~m}$ long, $21 \mathrm{~m}$ high road cutting in the Buçaco Ordovician-Silurian syncline in central Portugal, at km 55 of the highway IP3 (Slope 1, Fig. 1). It consists mainly of white, grey and purple impure quartzites with $>75 \%$ quartz with a weathering grade of W2-W3. The road cutting also has completely weathered (W4-W5) black schists.

The phyllites are intercalated with metagreywackes and the samples studied were collected from four rock slopes (2-5, Fig. 1) along highways IP3, IC6 and EN234 in central Portugal. They are all in the "Xisto-Grauváquico" Complex which has more recently been designated as "Dúrico-Beirão Supergroup" of Vendian-Cambrian age. The weathering grade of the phyllites and metagreywackes varied from $\mathrm{W} 2$ to $\mathrm{W} 4$, and sometimes W5; the phyllites are less weathered and stronger near the toe of the slope.

The phyllites are composed of quartz, muscovite, biotite, feldspar and chlorite minerals. The metagreywackes have the mineralogical composition of quartzwackes with a

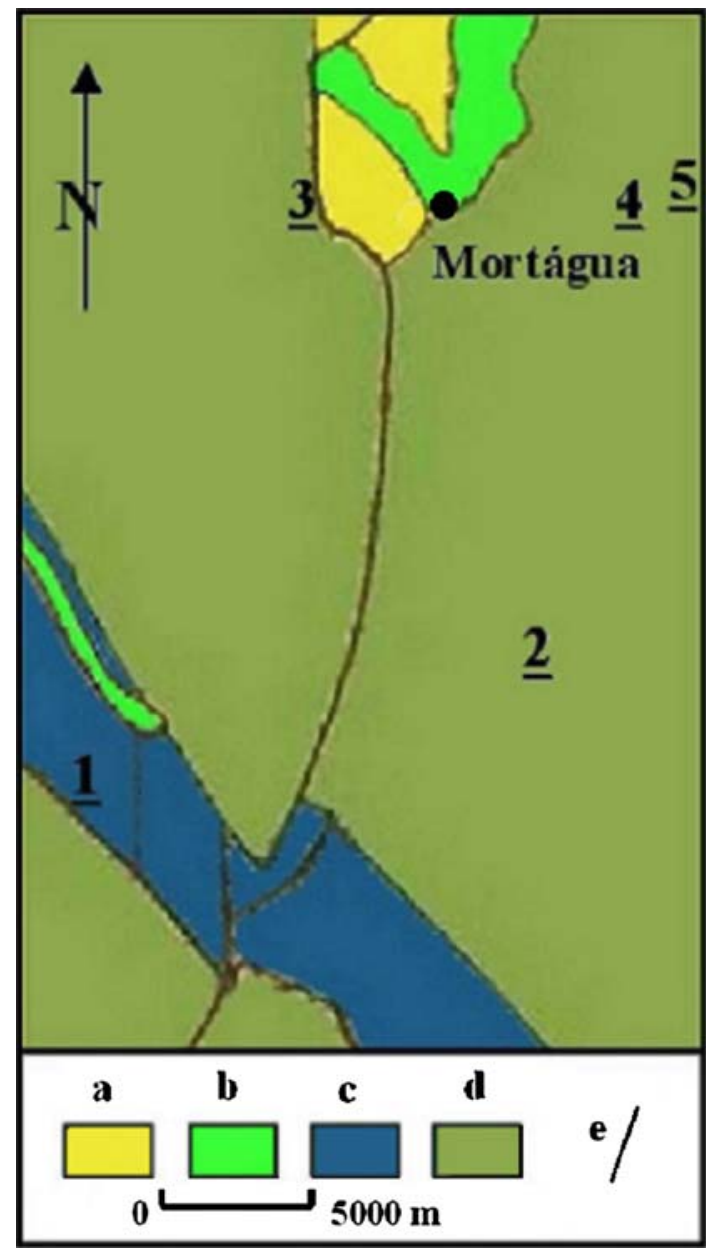

Fig. 1 Geological map adapted from SGP (1992). a Miocene; b Cretaceous; c Ordovician-Silurian; d "Xisto-Grauváquico" Complex; $\mathbf{e}$ fault; $1-5$ slope number 
low metamorphic grade. The metamorphism does not go beyond the greenschist facies (actinolite-chlorite-epidotealbite).

Tilt tests and rock joint shear tests were carried out in order to characterise the discontinuities and define the values of the JRC calculated. The rock samples were manually extracted from the slopes using hand tools, such as hammers and picks, to minimise disturbance of the discontinuity characteristics and where possible the discontinuities to be assessed were in the middle of the sampled rock block. The rock specimens for the joint shear tests were trimmed with cement mortar and the tests carried out in accordance with ISRM-TNG (2007).

\section{Values of the JRC graphic}

As seen from Table 1, the discontinuities in the quartzites give JRC graphic values which are generally higher than those for the metagreywackes, which in turn are higher than those for the phyllites (Fig. 2). It can also be seen that the JRC graphic values for the quartzites vary more than those for the other two lithologies, with the less weathered

Table 1 Joint roughness coefficient (JRC) graphic results

\begin{tabular}{|c|c|c|c|}
\hline Samples & $\begin{array}{l}\text { JRC } \\
\text { maximum } \\
\text { values }\end{array}$ & $\begin{array}{l}\text { JRC } \\
\text { minimum } \\
\text { values }\end{array}$ & $\begin{array}{l}\text { Number of } \\
\text { samples }\end{array}$ \\
\hline Slope 1 -W2 quartzites & 14 & 9 & 18 \\
\hline Slope 1 -W3 quartzites & 11 & 7 & 17 \\
\hline Slope $2-\mathrm{W} 2-\mathrm{W} 3$ phyllites & 8 & 4 & 15 \\
\hline Slope 2 -W4 phyllites & 8 & 3 & 18 \\
\hline $\begin{array}{l}\text { Slope } 2-\mathrm{W} 2 \\
\text { metagreywackes }\end{array}$ & 10 & 7 & 9 \\
\hline $\begin{array}{l}\text { Slope } 2-\mathrm{W} 3 \\
\quad \text { metagreywackes }\end{array}$ & 9 & 5 & 9 \\
\hline Slope 3-W2-W3 phyllites & 8 & 4 & 18 \\
\hline Slope 3 -W4 phyllites & 8 & 3 & 15 \\
\hline $\begin{array}{l}\text { Slope } 3-\mathrm{W} 2 \\
\text { metagreywackes }\end{array}$ & 9 & 7 & 7 \\
\hline Slope 4-W2-W3 phyllites & 7 & 3 & 20 \\
\hline Slope 4-W4 phyllites & 7 & 2 & 14 \\
\hline $\begin{array}{l}\text { Slope } 4-W 2 \\
\text { metagreywackes }\end{array}$ & 10 & 7 & 9 \\
\hline $\begin{array}{l}\text { Slope } 4-W 3 \\
\text { metagreywackes }\end{array}$ & 8 & 5 & 8 \\
\hline Slope $5-\mathrm{W} 2-\mathrm{W} 3$ phyllites & 8 & 3 & 20 \\
\hline Slope 5-W4 phyllites & 7 & 2 & 19 \\
\hline $\begin{array}{l}\text { Slope } 5-\mathrm{W} 2 \\
\text { metagreywackes }\end{array}$ & 9 & 6 & 8 \\
\hline $\begin{array}{l}\text { Slope } 5-\mathrm{W} 3 \\
\text { metagreywackes }\end{array}$ & 8 & 5 & 8 \\
\hline
\end{tabular}

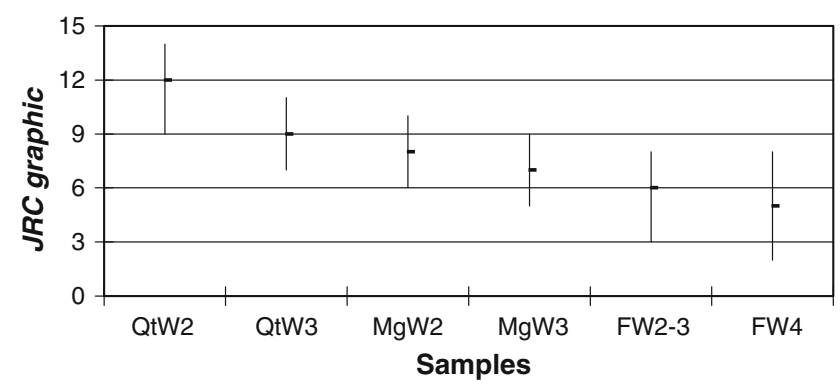

Fig. 2 Joint roughness coefficient (JRC) graphic results (Qtquartzites; $\mathrm{Mg}$ —-metagreywackes; F-phyllites)

W2 samples having higher values than the W3 samples, while weathering appears to have little effect for the phyllites and metagreywackes where the roughness is dominated by the schistosity.

\section{Comparison between JRC graphic and JRC calculated}

Comparisons between the results obtained on the phyllite specimens from slopes 2, 3, 4 and 5 with different degrees of weathering are shown in Table 1. As seen in Fig. 3, the calculated values for the individual rocks are significantly different.

Figure 3 shows for 6 of the 22 specimens from slope 2 (Fig. 3a), 6 of the 17 specimens from slope 4 (Fig. 3b) and 6 of the 15 from slope 5 (Fig. 3c), the JRC calculated values are outside of the maximum/minimum values for the JRC graphic values, i.e. approximately two-thirds of the JRC calculated results fall within the range of the measured JRC graphic (Fig. 4). Most of the anomalous results are lower than the minimum JRC graphic. The results are consistent with those of Hack (1998) who commented on the difficulty of determining a precise JRC graphic value. In contrast, the JRC calculated was defined in a more objective manner, through the use of tilt test results, and Eq. 2 and did not rely on the use of typical profiles.

\section{JRC and maximum amplitude roughness}

Barton and Bandis (1990) obtained JRC values through the use of an abacus in which the maximum amplitude (Amp) in $\mathrm{mm}$ and the length of the profile were considered, the latter ranging from $100 \mathrm{~mm}$ to $10 \mathrm{~m}$. They put forward the following relationship for the profiles with $100 \mathrm{~mm}$ in lengths:

$\mathrm{JRC}=4 x \mathrm{Amp}$

which they suggested would allow a quick estimation of the JRC values before carrying out a more precise determination. In the present work the Amp values of the discontinuity surfaces present in the samples were also 


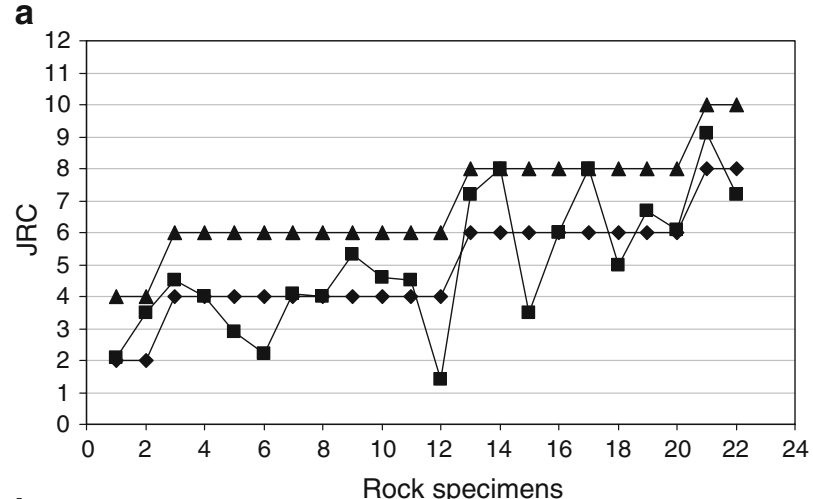

b

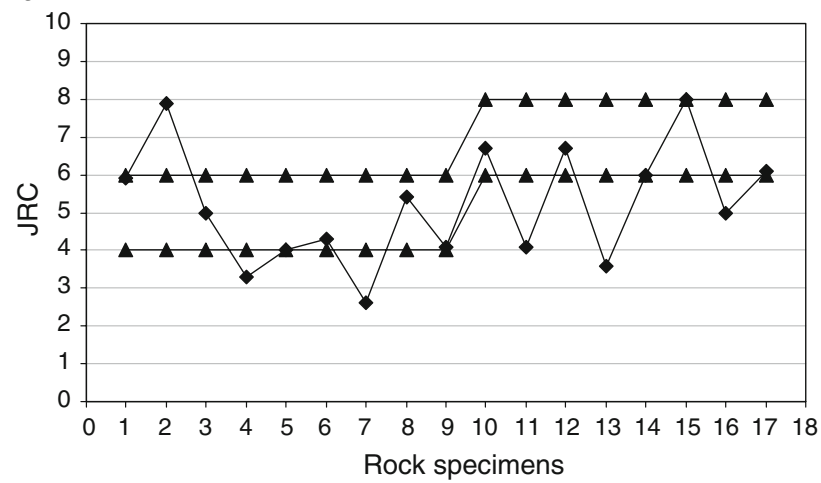

c

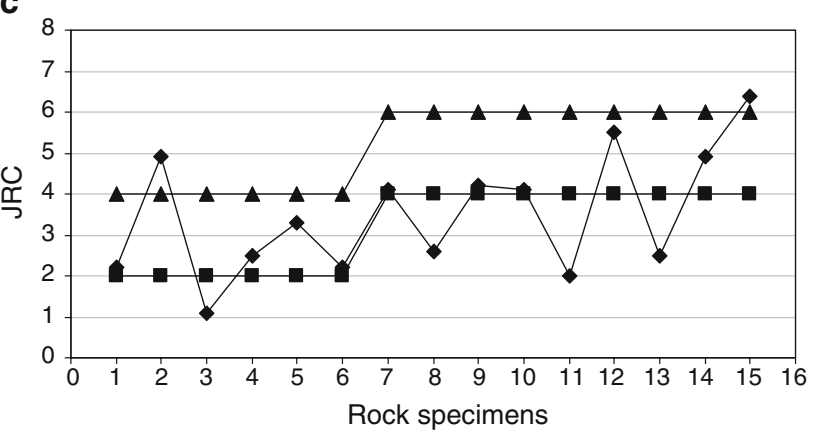

\section{$\neg$ Upper limit of the JRC graphic $\multimap$ JRC calculated \\ - Lower limit of the JRC graphic}

Fig. 3 Values of the JRC graphic and JRC calculated for the discontinuities of the phyllites: a slope 2 , b slope 4 and $\mathbf{c}$ slope 5

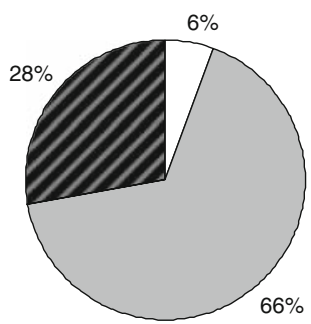

$\square$ JRC calculated superior to the upper limit of the JRC graphic class $\square$ JRC calculated between limits of the JRC graphic class

JRC calculated inferior to the lowest limit of the JRC graphic class

Fig. 4 Comparison in terms of percentage of the JRC calculated values in relation to the JRC graphical values

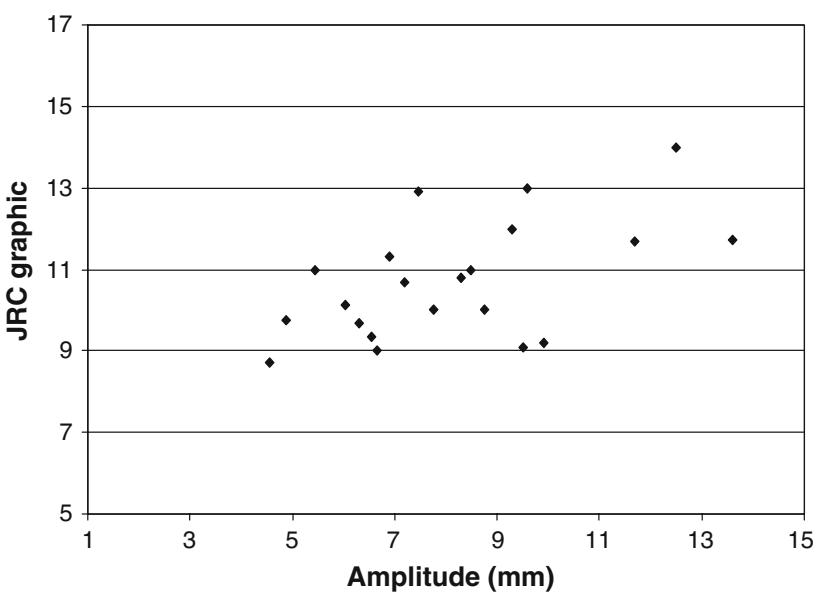

Fig. 5 Relation between the JRC graphic and the Amp of the discontinuities present in the W2 quartzites of slope 1-21 rock specimens (Pearson's correlation coefficient $=0.55$ and Spearman's rank correlation coefficient $=0.49$; the coefficients were statistically significant at the $95 \%$ confidence level)

measured in order to determine the possible correlation between the values of the JRC (calculated and graphic) and the Amp. It was assumed that both parameters present a normal distribution and only results with confidence levels equal or superior to $95 \%$ were considered.

The graph in Fig. 5 indicates some evidence of a trend between the Amp and the JRC graphic for the W2 quartzites in slope 1, although the points are somewhat scattered. For the 21 samples studied, the Spearman's rank correlation coefficient had a value of only 0.49 . In general, the W3 quartzites in slope 1 showed an increase in the JRC graphic with an increasing Amp (Fig. 6). The linear equations for the discontinuities in the $\mathrm{W} 2$ and $\mathrm{W} 3$ quartzites would be respectively:

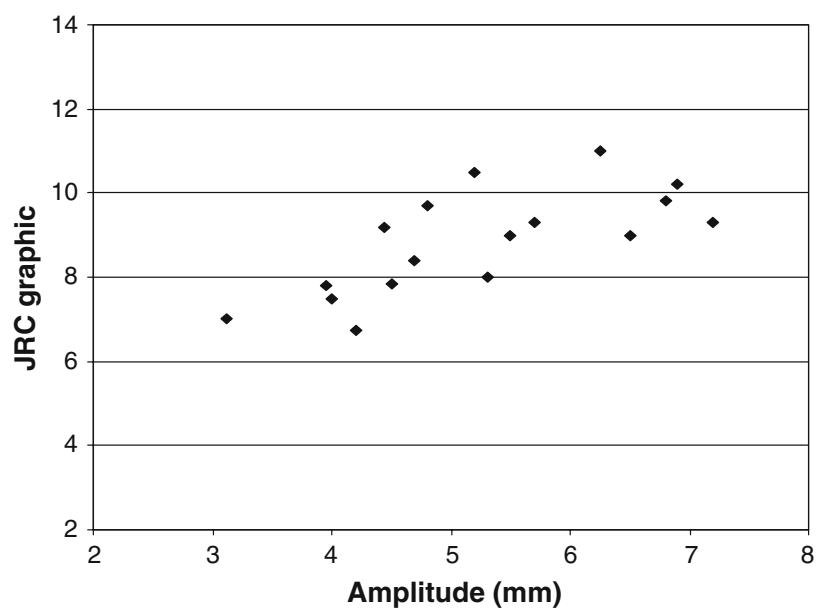

Fig. 6 Relation between the JRC graphic and the Amp for the discontinuities of the W3 quartzites of slope 1-17 rock specimens (Pearson's correlation coefficient $=0.72$ and Spearman's rank correlation coefficient $=0.74$; the coefficients were statistically significant at the $99 \%$ confidence level) 

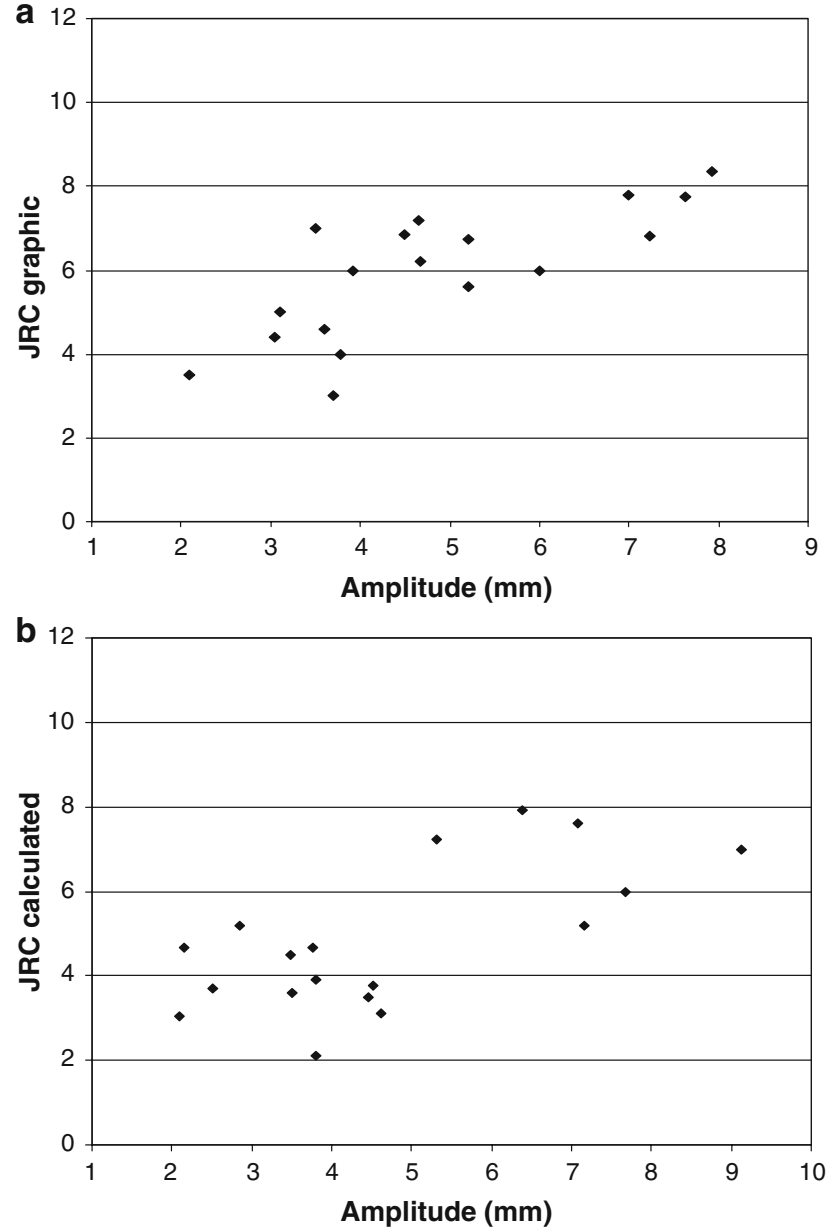

Fig. 7 a Relation between the JRC graphic and the Amp for the discontinuities of the W4 phyllites of slope 2-18 rock specimens (Pearson's correlation coefficient $=0.77$ and Spearman's rank correlation coefficient $=0.71$; the coefficients were statistically significant at the $99 \%$ confidence level). b Relation between the JRC calculated and the Amp for the discontinuities of the W4 phyllites of slope 2-18 rock specimens (Pearson's correlation coefficient $=0.68$ and Spearman's rank correlation coefficient $=0.55$, the coefficients were statistically significant at the $95 \%$ confidence level)

JRC graphic $=0.33 \times$ Amp +8.03

JRC graphic $=0.74 x$ Amp +4.95

Eqs. 4 and 5 show a better relationship than that achieved using the Barton and Bandis (1990) equation.

Figure $7 \mathrm{a}$ and $\mathrm{b}$ show the relationship between the JRC graphic and the JRC calculated and the amplitude for the W4 phyllites in slope 2; again the points are dispersed but the trend can be defined as:

$\mathrm{JRC}$ graphic $=0.70 \times \mathrm{Amp}+2.56$

JRC calculated $=0.81 x$ Amp +0.80

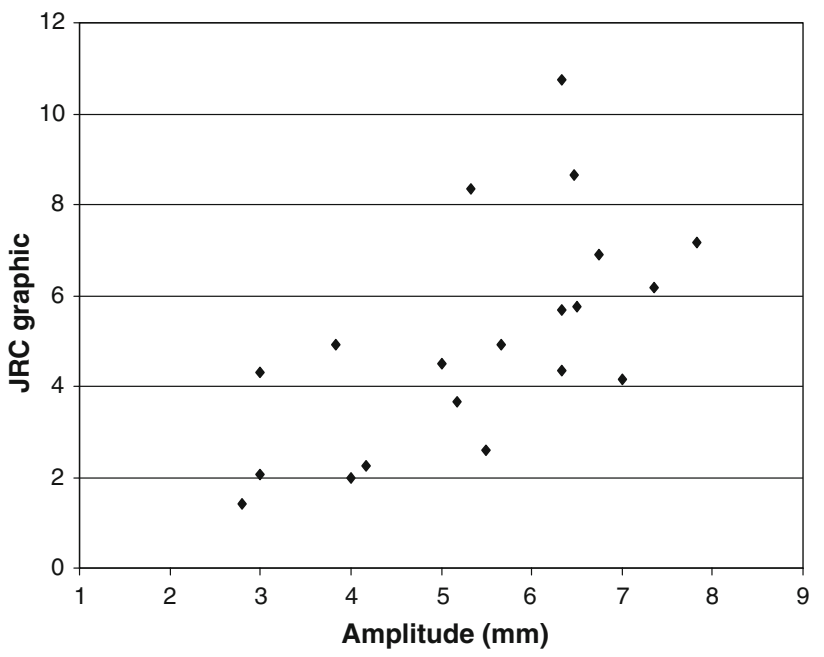

Fig. 8 Relation between the JRC graphic and the Amp for the discontinuities of the W3 and W4 phyllites of slope 4-20 rock specimens (Pearson's correlation coefficient $=0.63$ and Spearman's rank correlation coefficient $=0.66$; the coefficients were statistically significant at the $99 \%$ confidence level)

Equations 6 and 7 are considerably different from those proposed by Barton and Bandis (1990).

For the two parameters (the JRC graphic and the Amp) for the discontinuities in the W3 and W4 phyllites in slope 4 (Fig. 8), the following linear relationship was obtained:

JRC graphic $=0.39 x$ Amp +3.48

The slope of the line in Eq. 8 is not similar to that defined by the Barton and Bandis (1990) equation.

For the W3 phyllites in slope 5 (Figs. 9a, b), the relationship between the JRC graphic and JRC calculated and Amp can be expressed by:

$\mathrm{JRC}$ graphic $=0.93 \times \mathrm{Amp}+2.51$

JRC calculated $=1.11 \times$ Amp +0.42

In order to clarify the relationships, the values of the Amp and the JRC graphic of all the discontinuities of the phyllites studied were plotted in Fig. 10. The relationship obtained can be expressed as:

JRC graphic $=0.46 x \mathrm{Amp}+3.74$

Not surprisingly, the Pearson and Spearman coefficient correlations are not as good as those for the separate relationship, but in contrast to most of the other equations determined in this study, Eq. 11 is relatively close to Eq. 8.

As seen in Fig. 11, if the anomalous values of 6.33 (Amp) and 10.73 (JRC graphic) are ignored, the 56 specimens follow a more distinct trend which can be expressed as:

JRC graphic $=0.55 x$ Amp +3.37

Table 2 shows the results for which correlations with a 99\% confidence level were achieved (with the exception of 

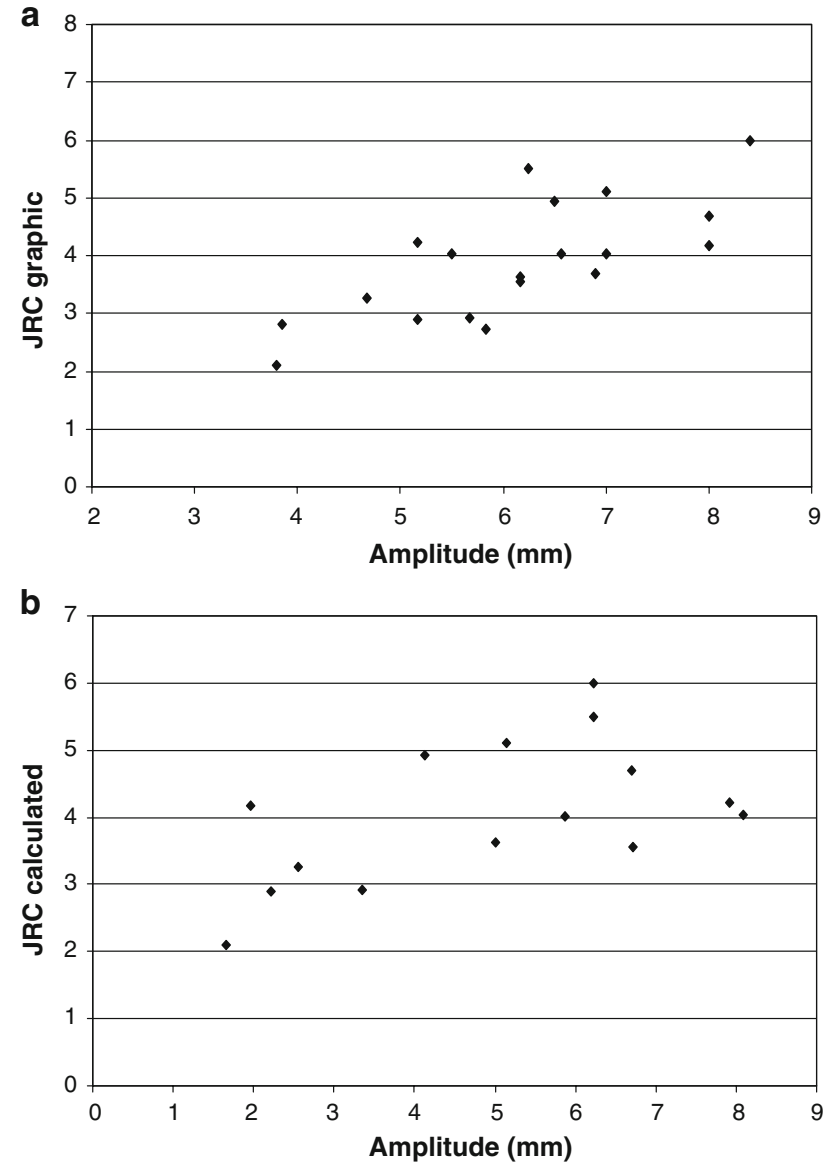

Fig. 9 a Relation between the JRC graphic and the Amp for the discontinuities of the W3 phyllites of slope 5-19 rock specimens (Pearson's correlation coefficient $=0.74$ and Spearman's rank correlation coefficient $=0.73$; the coefficients were statistically significant at the $99 \%$ confidence level). b Relation between the JRC calculated and the Amp for the discontinuities of the W3 phyllites of slope 5-15 rock specimens (Pearson's correlation coefficient $=0.54$, this coefficient was statistically significant at the 95\% confidence level. Spearman's rank correlation coefficient $=0.49$; this coefficient was not statistically significant at the $95 \%$ confidence level)

values marked with an ${ }^{\mathrm{a}}$ ). The results indicate that although the JRC graphic and the Amp parameters generally present a directly proportional relationship, this is very variable and specific for each group of surface discontinuities analysed, making it clear that the definition of roughness does not exclusively depend on its maximum amplitude.

\section{Comparison of the JRC calculated values determined by the tilt tests and the rock joint shear tests}

The discontinuities for the rock joint shear tests were bedding for the quartzites and schistosity for the phyllites. The results of the JRC calculated (obtained by Eq. 2) were compared with the values from the rock joint shear tests

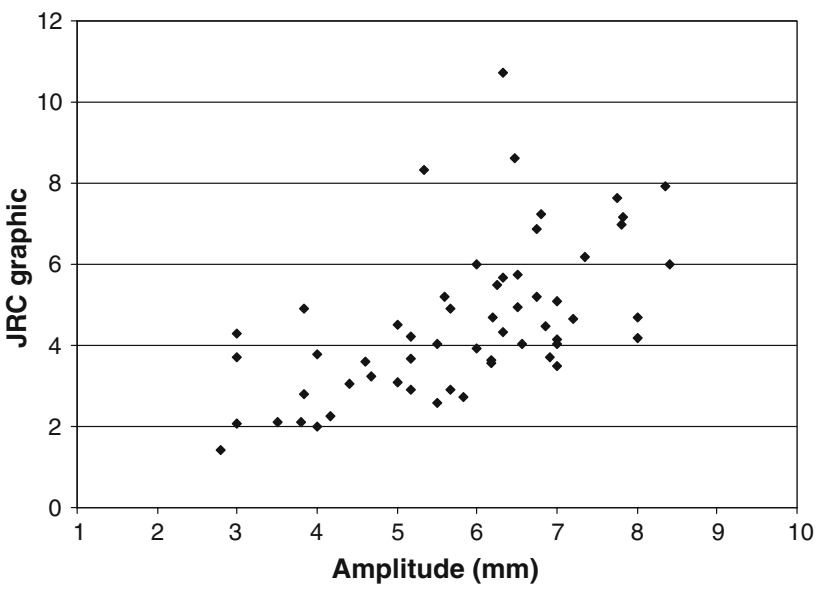

Fig. 10 Relation between the JRC graphic and the Amp for the discontinuities of the phyllites of slopes 2, 3, 4 and 5-57 rock specimens (Pearson's correlation coefficient $=0.58$ and Spearman's rank correlation coefficient $=0.63$; the coefficients were statistically significant at the $99 \%$ confidence level)

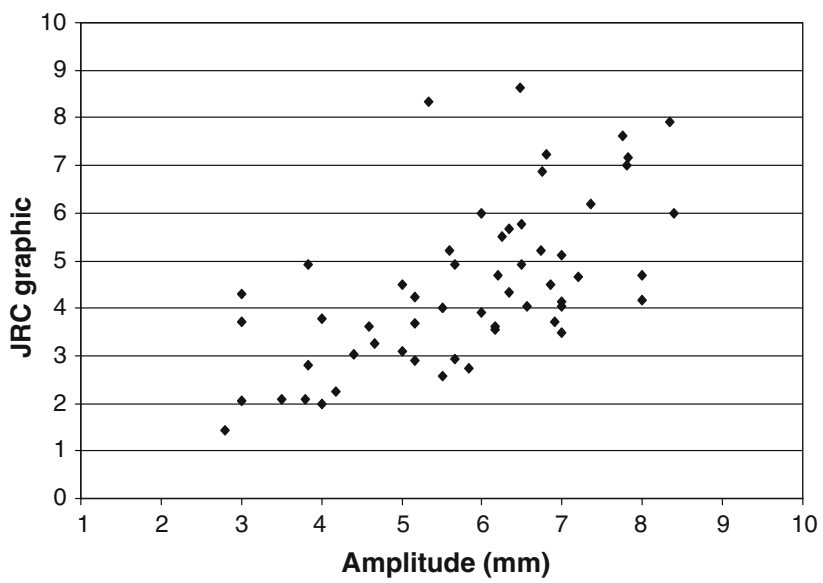

Fig. 11 Relation between the JRC graphic and the Amp for the discontinuities of the phyllites of slopes 2, 3, 4 and 5-56 rock specimens (Pearson's correlation coefficient $=0.63$ and Spearman's rank correlation coefficient $=0.64$; the coefficients were statistically significant at the $99 \%$ confidence level)

(Eq. 1 was used to determine the JRC calculated values by back-analysis).

Using Eq. 1, for lower normal stresses, joints with greater roughness produced higher $\phi$ values. A reduction in the JRC calculated values is associated with the increase in the JCS and $\phi_{\mathrm{r}}$ when the normal and tangential stresses are considered constant.

Tables 3, 4, 5 and 6 show that the JRC calculated values defined by Eq. 2 for the phyllites in slopes 2, 3, 4 and 5 are generally higher than those obtained by back-analysis and Eq. 1. It should be noted that the JCS values used in Eq. 1 were established through the use of the Schmidt hammer rebound values and the bulk density of the rock material. 
Table 2 Correlation values and linear models of the JRC and the Amp of the discontinuities studied

\begin{tabular}{lllll}
\hline Rock joints & $\begin{array}{l}\text { Pearson's } \\
\text { correlation } \\
\text { coefficient }\end{array}$ & $\begin{array}{l}\text { Spearman's rank } \\
\text { correlation } \\
\text { coefficient }\end{array}$ & $\begin{array}{l}\text { Number of } \\
\text { samples }\end{array}$ & Linear model \\
\hline W2 quartzites of slope 1 & $0.55^{\text {a }}$ & $0.49^{\text {a }}$ & 21 & JRC graphic $=0.33 \times$ Amp +8.03 \\
W3 quartzites of slope 1 & 0.72 & 0.74 & 17 & JRC graphic $=0.74 \times$ Amp +4.95 \\
W4 phyllites of slope 2 & 0.77 & 0.71 & 18 & JRC graphic $=0.70 \times$ Amp +2.56 \\
W4 phyllites of slope 2 & $0.68^{\text {a }}$ & $0.55^{\text {a }}$ & 18 & JRC calculated $=0.81 \times$ Amp +0.80 \\
W3 and W4 phyllites of slope 4 & 0.63 & 0.66 & 20 & JRC graphic $=0.39 \times$ Amp +3.48 \\
W3 phyllites of slope 5 & 0.74 & 0.73 & 19 & JRC graphic $=0.93 \times$ Amp +2.51 \\
W3 phyllites of slope 5 & $0.54^{\text {a }}$ & $0.49^{\text {a }}$ (not statistically & 15 & JRC calculated $=1.11 \times$ Amp +0.42 \\
Phyllites of slopes 2, 3, 4 and 5 & 0.58 & 0.63 & 57 & JRC graphic $=0.46 \times$ Amp +3.74 \\
Phyllites of slopes 2, 3, 4 and 5 & 0.63 & 0.64 & 56 & JRC graphic $=0.55 \times$ Amp +3.37 \\
\hline
\end{tabular}

${ }^{a}$ For a $95 \%$ confidence level

${ }^{b}$ Removal of a pair of values distant from the cloud of points

Table 3 JRC calculated values of the joints of the phyllites belonging to slope 2

\begin{tabular}{lll}
\hline Rock specimens & $\begin{array}{l}\text { JRC calculated } \\
\text { through Eq. 2 }\end{array}$ & $\begin{array}{l}\text { JRC calculated } \\
\text { through Eq. 1 }\end{array}$ \\
\hline S 2-1 W4 phyllites & 2.1 & 2.1 \\
S 2-3 W4 phyllites & 4.5 & 4.2 \\
S 2-4 W4 phyllites & 9.1 & 8.0 \\
S 2-5 W4 phyllites & 7.2 & 5.3 \\
S 2-6 W3 phyllites & 8.0 & 5.3 \\
S 2-7 W2-W3 phyllites & 7.2 & 5.9 \\
S 2-8 W3 phyllites & 6.4 & 6.0 \\
S 2-11 W3 phyllites & 4.0 & 3.9 \\
S 2-12 W3 phyllites & 2.9 & 3.3 \\
S 2-16 W3 phyllites & 2.2 & 1.0 \\
S 2-20 W3 phyllites & 4.6 & 3.8 \\
S 2-22 W3 phyllites & 4.5 & 4.5 \\
\hline
\end{tabular}

Table 4 JRC calculated values of the joints of the phyllites belonging to slope 3

\begin{tabular}{lll}
\hline Rock specimens & $\begin{array}{l}\text { JRC calculated } \\
\text { through Eq. 2 }\end{array}$ & $\begin{array}{l}\text { JRC calculated } \\
\text { through Eq. 1 }\end{array}$ \\
\hline S 3-20 W4 phyllites & 3.2 & 2.9 \\
S 3-21 W4 phyllites & 1.3 & 3.1 \\
S 3-2A W3-W4 phyllites & 5.0 & 2.4 \\
S 3-3 W3-W4 phyllites & 3.4 & 4.4 \\
S 3-4A W3 phyllites & 2.8 & 0.8 \\
S 3-4B W3-W4 phyllites & 3.3 & 1.2 \\
S 3-4 W3-W4 phyllites & 3.1 & 1.0 \\
\hline
\end{tabular}

When determining the JRC calculated from Eq. 1, in order to be able to compare the different values found, the same normal stress was always used $(0.1 \mathrm{MPa})$. Only joints
Table 5 JRC calculated values of the joints of the phyllites belonging to slope 4

\begin{tabular}{lll}
\hline Rock specimens & $\begin{array}{l}\text { JRC calculated } \\
\text { through Eq. 2 }\end{array}$ & $\begin{array}{l}\text { JRC calculated } \\
\text { through Eq. 1 }\end{array}$ \\
\hline S 4-1A W3 phyllites & 5.9 & 3.3 \\
S 4-1B W3 phyllites & 7.9 & 4.6 \\
S 4-1C W3 phyllites & 5.0 & 3.3 \\
S 4-1D W3 phyllites & 6.7 & 6.3 \\
S 4-1E W3 phyllites & 3.3 & 3.4 \\
S 4-1F W3 phyllites & 4.1 & 3.3 \\
S 4-1G W3 phyllites & 2.6 & 2.5 \\
S 4-2A W3 phyllites & 4.0 & 1.7 \\
S 4-2B W3 phyllites & 4.3 & 2.7 \\
S 4-4 W3 phyllites & 5.4 & 3.6 \\
S 4-5A W3 phyllites & 4.1 & 3.0 \\
S 4-20 W4 phyllites & 6.7 & 5.4 \\
S 4-24 W3 phyllites & 8.0 & 7.4 \\
\hline
\end{tabular}

Table 6 JRC calculated values of the joints of the phyllites belonging to slope 5

\begin{tabular}{lll}
\hline Rock specimens & $\begin{array}{l}\text { JRC calculated } \\
\text { through Eq. 2 }\end{array}$ & $\begin{array}{l}\text { JRC calculated } \\
\text { through Eq 1 }\end{array}$ \\
\hline S 5-13 W3 phyllites & 4.1 & 4.0 \\
S 5-20 W3 phyllites & 2.2 & 2.6 \\
S 5-21 W3 phyllites & 4.9 & 4.0 \\
S 5-26 W3 phyllites & 1.1 & 1.0 \\
S 5-40 W3 phyllites & 2.6 & 3.2 \\
S 5-C1A W4 phyllites & 3.3 & 1.2 \\
S 5-C1B W4 phyllites & 4.2 & 1.8 \\
S 5-C1C W4 phyllites & 4.1 & 3.0 \\
S 5-E1A W4 phyllites & 2.2 & 1.4 \\
S 5-E1B W4 phyllites & 2.0 & 2.0 \\
S 5-E2A W4 phyllites & 5.5 & 4.2 \\
S 5-E2B W4 phyllites & 2.5 & 1.6 \\
S 5-E2C W4 phyllites & 4.9 & 4.1 \\
\hline
\end{tabular}




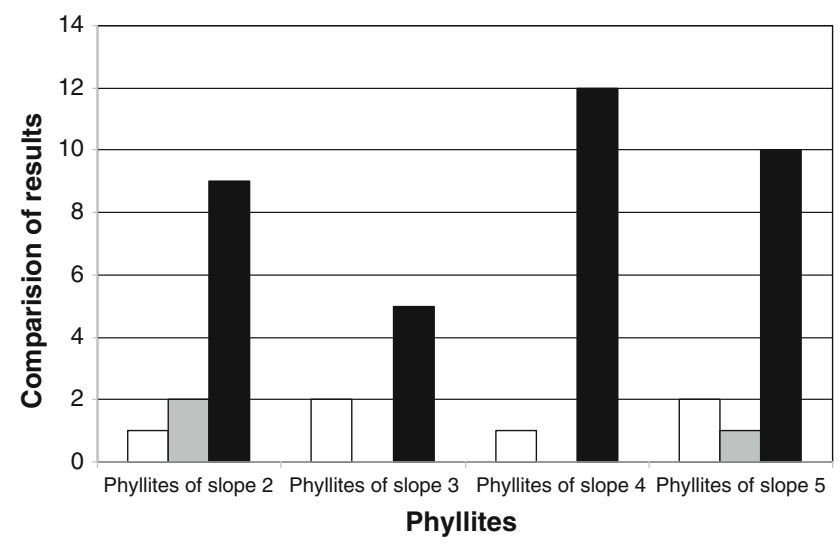

Fig. 12 Bar graph showing the comparison between the results of the JRC calculated obtained by Eqs. 1 and 2 (open square-JRC calculated defined by Eq. 1 superior to the JRC calculated defined by Eq. 2, grey filled square-JRC calculated defined by Eq. 1 identical to the JRC calculated defined by Eq. 2, black filled square-JRC calculated by Eq. 1 inferior to the JRC calculated defined by Eq. 2)

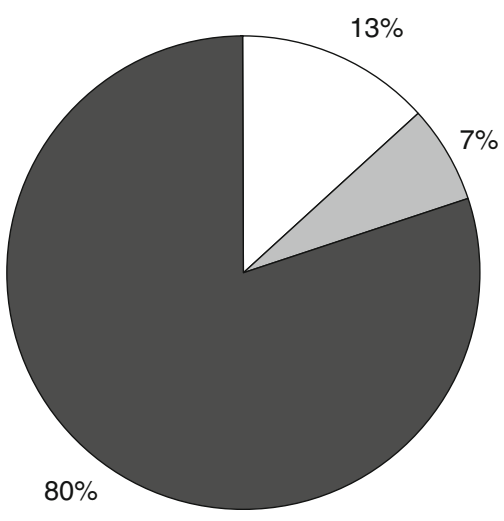

Fig. 13 Pie graph showing the comparison, in percentage terms, between the results of the JRC calculated obtained by Eqs 1 and 2 (open square-JRC calculated defined by Eq. 1 superior to the JRC calculated defined by Eq. 2, grey filled square-JRC calculated defined by Eq. 1 identical to the JRC calculated defined by Eq. 2, black filled square-JRC calculated by Eq. 1 inferior to the JRC calculated defined by Eq. 2)

with apparent cohesion values of $<2 \mathrm{kPa}$ in the rock shear tests were used so that comparisons could be made with tilt tests results.

In 36 of the 45 rock specimens (approximately 80\%), the JRC calculated values defined by Eq. 1 were lower than those established by Eq. 2 (Figs. 12, 13). For approximately half of the specimens, the difference between the JRC calculated values obtained from Eqs. 1 and 2 was less than $20 \%$.

The lower JRC calculated values obtained from the rock joint shear tests can be explained by the normal stresses being higher in these compared with the tilt tests, which may also account for the lower friction angles obtained by the rock joint shear tests. The difference might be related to

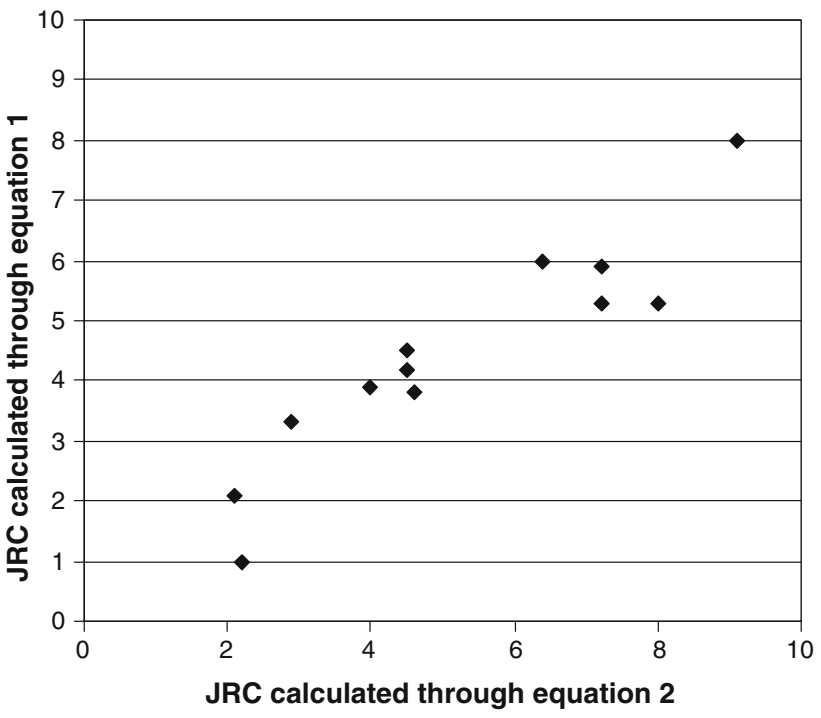

Fig. 14 JRC calculated values defined by tilt tests and rock joint shear tests of the discontinuities of W2-W3 phyllites of slope 2 (linear model: $Y=0.54+0.75 X$, Pearson's correlation coefficient $=0.93$ and Spearman's rank correlation coefficient $=0.89$; the coefficients were statistically significant at the $99 \%$ confidence level)

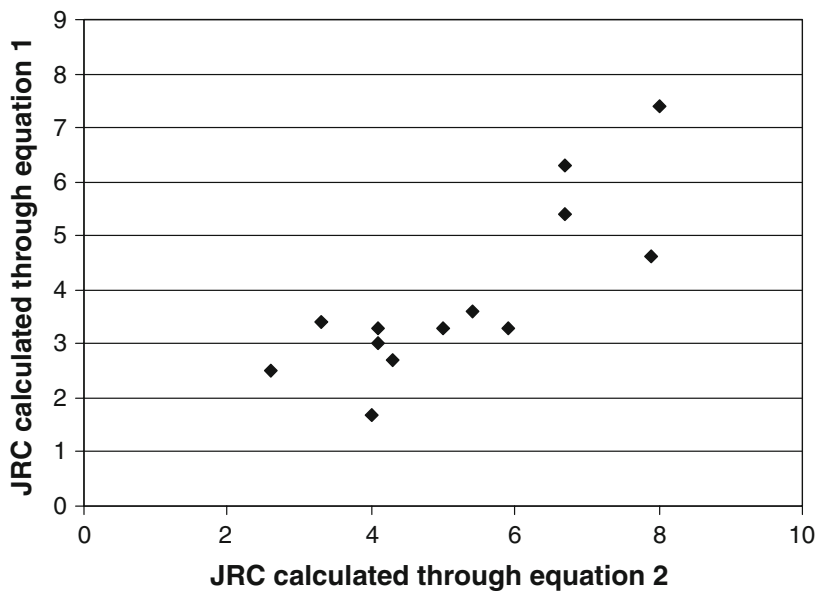

Fig. 15 JRC calculated values defined by tilt tests and rock joint shear tests of the discontinuities of W3-W4 phyllites of slope 4 (linear model: $Y=-0.15+0.77 X$, Pearson's correlation coefficient $=0.82$ and Spearman's rank correlation coefficient $=0.81$; the coefficients were statistically significant at the $99 \%$ confidence level)

the possible damage and wear of the asperities of the joint surfaces, as frequently occurs with shear displacement during the rock shear tests. In the tilt tests, the shear displacements were characterised by the transposition of the irregularities, which favours the increase of the $\alpha$ values. Despite these differences, a direct proportional relationship could be identified.

The possible relationships between the JRC calculated values obtained by Eqs. 1 and 2 for the discontinuities of 


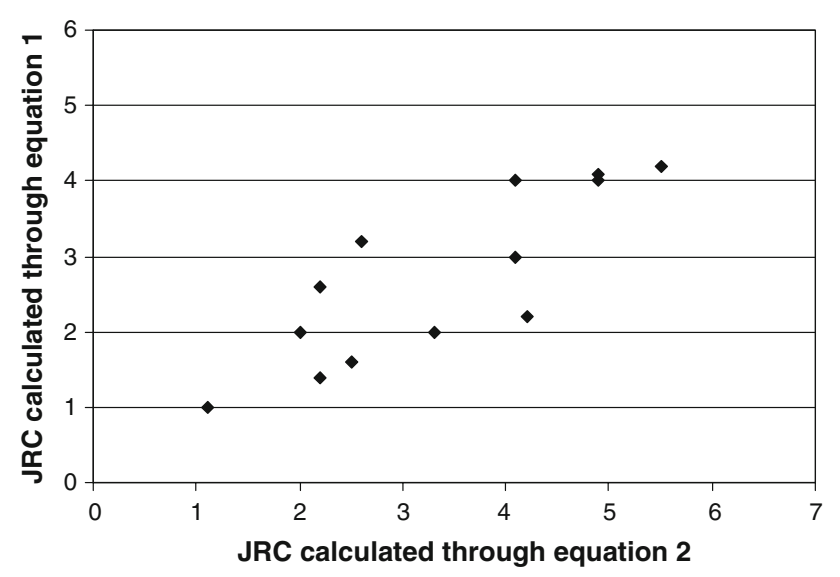

Fig. 16 JRC calculated values defined by tilt tests and rock joint shear tests of the discontinuities of W3-W4 phyllites of slope 5 (linear model: $Y=0.41+0.69 X$, Pearson's correlation coefficient $=0.83$ and Spearman's rank correlation coefficient $=0.83$; the coefficients were statistically significant at the $99 \%$ confidence level)

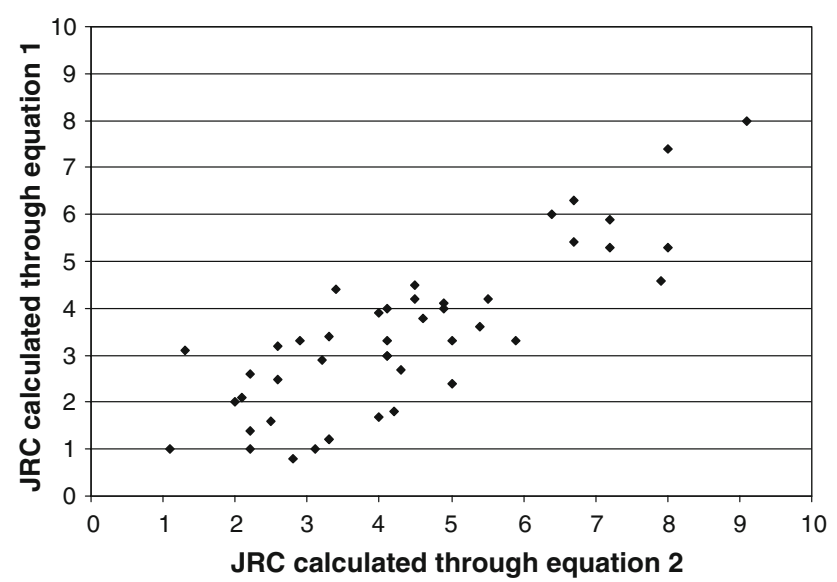

Fig. 17 JRC calculated values defined by tilt tests and rock joint shear tests of the discontinuities of phyllites of slopes 2, 3, 4 and 5 (linear model: $Y=0.20+0.74 X$, Pearson's correlation coefficient $=0.83$ and Spearman's rank correlation coefficient $=0.79$; the coefficients were statistically significant at the $99 \%$ confidence level)

the phyllites are presented in Figs. 14, 15, 16 and 17. With the exception of the phyllites in slopes 3, all the other relationships achieved a $99 \%$ confidence level.
An analysis was also carried out considering all the JRC calculated values for the phyllites (Fig. 17). Although there is some scatter, the correlation is reasonably high, with the Pearson and Spearman's correlation coefficients values of 0.83 and 0.79 , respectively (statistically significant at the 99\% confidence level). The Senedecor's $F$ test indicated the results were valid for a probability of $99 \%$.

The forecast linear models showed slope values between 0.69 and 0.77 and constants (points at which the lines cross the $y$-axis) very close to null values (Table 7). These results are consistent with the slightly rough and smooth joint surfaces and very low or even null apparent cohesion values.

\section{Conclusions}

The roughness of discontinuities can be characterised by the JRC, which in this work was defined by graphical and analytical methods. In general, it was found that, for the same weathering degree, the quartzite joints JRC graphic values were higher than those for the metagreywacke and phyllite joints.

The JRC values obtained by comparison with typical profiles for standard roughness and the maximum amplitude were generally less precise than the JRC values obtained by tilt tests (JRC calculated).

Approximately $34 \%$ of the results from the phyllites obtained for the JRC calculated did not fall within the range of JRC graphic values. This is likely to be related to the methodological differences and the degree of subjectivity in determining the latter.

For the quartzites and phyllites a direct proportional relationship was established between the amplitude values and the JRC graphic values, although the expressions varied and differed from those established by Barton and Bandis (1990).

When the results of the JRC calculated defined by Eq. 2 (tilt tests) and those determined by Eq. 1 (rock joint shear tests) for the phyllites were compared, it was found that for approximately $80 \%$ of the samples, the JRC calculated values obtained by the rock joint shear tests were lower than those obtained by the tilt tests. This may be a
Table 7 Correlation values and linear models of the JRC calculated values defined by Eq. 2 (tilt tests) and Eq. 1 (rock joint shear tests)

\begin{tabular}{lllll}
\hline Rock joints & $\begin{array}{l}\text { Pearson's } \\
\text { correlation } \\
\text { coefficient }\end{array}$ & $\begin{array}{l}\text { Spearman's } \\
\text { rank correlation } \\
\text { coefficient }\end{array}$ & $\begin{array}{l}\text { Number of } \\
\text { samples }\end{array}$ & Linear model \\
\hline W2-W4 phyllites of slope 2 & 0.93 & 0.89 & 12 & $Y=0.75 X+0.54$ \\
W3-W4 phyllites of slope 4 & 0.82 & 0.81 & 13 & $Y=0.77 X-0.15$ \\
W3-W4 phyllites of slope 5 & 0.63 & 0.66 & 13 & $Y=0.69 X+0.41$ \\
Phyllites of slopes 2, 3, 4 and 5 & 0.74 & 0.73 & 45 & $Y=0.74 X+0.20$ \\
\hline
\end{tabular}


consequence of the greater wear and tear of the asperities during the rock joint shear tests.

The study has indicated the importance of specifying the method used to obtain the JRC, i.e. by graphical or analytical means, and also whether the determination was carried out using tilt tests or rock joint shear tests.

\section{References}

Barton NR, Bandis SC (1990) Review of predictive capabilities of JRC-JCS model in engineering practice. In: Proceedings of the international conference on rock joints. Proc Int Conf Rock Joints $603-610$
Barton NR, Choubey V (1977) The shear strength of rock joints in theory and practice. Rock Mech 10:1-54

Hack R (1998) Slope stability probability classification. In: ITC, International Institute for Geo-Information and Earth Sciences. Enschede, The Netherlands, $258 \mathrm{pp}$

Hack R, Price D, Rengers N (2003) A new approach of rock slope stability-a probability classification (SSPC). Bull Eng Geol Environ 62:167-184

Hoek E (2007) Practical rock engineering. Course notes, Hoek Corner. http://www.rocscience.com

International Society for Rock Mechanics-Turkish National Group (ISRM-TNG) (2007) The complete ISRM suggested methods for rock characterization, testing and monitoring: 1974-2006. In: Ulusay R, Hudson JA (eds) Ankara, Turkey, pp 165-173

Serviços Geológicos de Portugal (SGP) (1992) Carta geológica de Portugal—escala 1:500 000. Lisboa, Portugal 